\title{
The contribution of anthropogenic bromine emissions to past stratospheric ozone trends: a modelling study
}

\author{
B.-M. Sinnhuber ${ }^{1}$, N. Sheode ${ }^{1}$, M. Sinnhuber ${ }^{1}$, M. P. Chipperfield ${ }^{2}$, and W. Feng ${ }^{2}$ \\ ${ }^{1}$ Institute of Environmental Physics, University of Bremen, Bremen, Germany \\ ${ }^{2}$ School of Earth and Environment, University of Leeds, Leeds, UK
}

Received: 17 May 2006 - Published in Atmos. Chem. Phys. Discuss.: 13 July 2006

Revised: 3 April 2009 - Accepted: 15 April 2009 - Published: 30 April 2009

\begin{abstract}
Bromine compounds play an important role in the depletion of stratospheric ozone. We have calculated the changes in stratospheric ozone in response to changes in the halogen loading over the past decades, using a twodimensional (latitude/height) model constrained by source gas mixing ratios at the surface. Model calculations of the decrease of total column ozone since 1980 agree reasonably well with observed ozone trends, in particular when the contribution from very short-lived bromine compounds is included. Model calculations with bromine source gas mixing ratios fixed at 1959 levels, corresponding approximately to a situation with no anthropogenic bromine emissions, show an ozone column reduction between 1980 and 2005 at Northern Hemisphere mid-latitudes of only $\approx 55 \%$ compared to a model run including all halogen source gases. In this sense anthropogenic bromine emissions are responsible for $\approx 45 \%$ of the model estimated column ozone loss at Northern Hemisphere mid-latitudes. However, since a large fraction of the bromine induced ozone loss is due to the combined $\mathrm{BrO} / \mathrm{ClO}$ catalytic cycle, the effect of bromine would have been smaller in the absence of anthropogenic chlorine emissions. The chemical efficiency of bromine relative to chlorine for global total ozone depletion from our model calculations, expressed by the so called $\alpha$-factor, is 64 on an annual average. This value is much higher than previously published results. Updates in reaction rate constants can explain only part of the differences in $\alpha$. The inclusion of bromine from very short-lived source gases has only a minor effect on the global mean $\alpha$-factor.
\end{abstract}

Correspondence to: B.-M. Sinnhuber (bms@iup.physik.uni-bremen.de)

\section{Introduction}

Bromine compounds play an important role in the depletion of stratospheric ozone (World Meteorological Organization, 2007). Anthropogenic emissions of bromine containing source gases have resulted in more than a doubling of the atmospheric bromine loading from methyl bromide and the halons between 1980 and the late 1990s (Montzka et al., 2003). There is now a lot of evidence that also short-lived bromine compounds, mainly of natural origin, contribute significantly to the stratospheric bromine loading (e.g., Pfeilsticker et al., 2000; Sinnhuber et al., 2002; Schofield et al., 2004; Salawitch et al., 2005; Sinnhuber et al., 2005; Sioris et al., 2006). Bromine from short-lived compounds may have contributed to the stratospheric ozone decrease even if there is no trend in the contribution from short-lived compounds due to the coupling between bromine and chlorine containing catalytic ozone loss cycles. Salawitch et al. (2005) have shown that a few parts per trillion by volume (pptv) of additional bromine from short-lived compounds can result in a significantly larger calculated downward ozone trend, in particular for periods of enhanced aerosol loading following large volcanic eruptions, resulting in a better agreement between modelled and observed ozone trends during these periods. Feng et al. (2007) used a three-dimensional (3-D) chemical transport model to investigate the impact of an enhanced bromine loading due to short-lived species on stratospheric ozone. They found that for an additional $5 \mathrm{pptv}$ of bromine from short-lived species mid-latitude column ozone decreases by about 10 Dobson units (DU) but the impact on ozone trends is generally small, except for periods of enhanced aerosol loading.

Published by Copernicus Publications on behalf of the European Geosciences Union. 
Here we now address the question: by how much have anthropogenic bromine emissions contributed to the decrease of stratospheric ozone over the past decades, taking into account the additional background of bromine from short-lived compounds. We do this by performing a set of calculations with a two-dimensional (2-D) model with interactive chemistry, radiation and transport. The model calculations shown here are part of a set of model runs we performed in support of the 2006 WMO/UNEP Ozone Assessment (World Meteorological Organization, 2007). Here we show a set of transient model calculations over the past decades with different bromine source gas scenarios employed, as well as results from a set of sensitivity runs that allow us to specify the relative effectiveness of bromine compared to chlorine for stratospheric ozone depletion. Ultimately one would wish to perform this kind of calculations with coupled 3-D chemistryclimate-models due to their better representation of dynamics and transport. In particular, 3-D models will have a better representation of the interaction of transport and chemistry in the high-latitude stratosphere where spring-time ozone loss is due to combined chlorine and bromine chemistry, and they will provide a much more realistic description of the changes in dynamics and transport as a result of changing concentrations of greenhouse gases. However, 3-D chemistry-climatemodels are computationally very expensive, compared to 2$\mathrm{D}$ models, and are just beginning to become available for assessment studies.

\section{Model and source gas scenarios}

The model used in this study is the 2-D transport, chemistry and radiation model most recently described by Chipperfield and Feng (2003). It uses the dynamical core of the so called "two-and-a-half-dimensional" THINAIR model (Kinnersley, 1996) together with the chemistry scheme from the SLIMCAT model (Chipperfield, 1999). It extends from the ground to about $100 \mathrm{~km}$ altitude with a vertical resolution of about $3.5 \mathrm{~km}$ with 28 isentropic levels and a horizontal resolution of $9.5^{\circ}$. The stratospheric dynamics are forced by the amplitudes of waves 1 to 3 of the Montgomery potential at the $380 \mathrm{~K}$ isentrope (essentially the same as the amplitudes of the $100 \mathrm{hPa}$ geopotential waves). Here we use the daily Montgomery potential from meteorological analyses with a repeating annual cycle for the period of May 1980 to April 1981. There is no quasi biennial oscillation (QBO) in the model, i.e., the modelled tropical stratospheric wind is always in a weak easterly state. There is no solar cycle in the model runs presented here. Kinnersley (1998) and Kinnersley and Tung (1998) showed by using a different version of this model that inclusion of the interannual variability of extratropical planetary wave activity as well as inclusion of the equatorial QBO led to an interannual variability of ozone that resembled many features of the observed interannual variability. As we have used no interannual variability in the dynamical forcing here, all interannual variability comes from changes in the source gases and aerosol surface area. Stratospheric temperatures, dynamics and transport are calculated interactively using the modelled concentrations of the radiatively active gases ozone $\left(\mathrm{O}_{3}\right)$, carbon dioxide $\left(\mathrm{CO}_{2}\right)$, methane $\left(\mathrm{CH}_{4}\right)$, nitrous oxide $\left(\mathrm{N}_{2} \mathrm{O}\right)$, and nitrogen dioxide $\left(\mathrm{NO}_{2}\right)$. The model does not take into account direct radiative effects from CFCs. Surface temperatures follow a specified annual cycle and are held constant during the model integrations.

Source gas surface mixing ratios and the stratospheric aerosol surface area were specified according to the WMO/UNEP model scenario. The aerosol surface area density was calculated from measurements by the SAGE I, SAGE II, SAM II, and SME satellite instruments (David B. Considine, personal communication, 2005). Reaction rate constants and photolysis cross sections are taken from JPL06 recommendations (Sander et al., 2006).

Although we calculate chemistry down to the surface, there is no detailed tropospheric chemistry included in the model calculations presented here. This - together with the fact that tropospheric transport processes are highly simplified in a 2-D model - means that modelled changes in tropospheric ozone will probably not be realistic.

Figure 1 shows the chlorine and bromine loading from the specified scenario. Anthropogenic emissions have led to a large increase of bromine over the past about 25 years. The bromine loading due to methyl bromide $\left(\mathrm{CH}_{3} \mathrm{Br}\right)$, Halon$1301\left(\mathrm{CBrF}_{3}\right)$, and Halon-1211 $\left(\mathrm{CBrClF}_{2}\right)$ have increased by about 7 pptv between 1980 and 2005, compared to an increase of the chlorine loading by about 1000 pptv over the same period. Note that in accord with the $2006 \mathrm{WMO} / \mathrm{UNEP}$ Ozone Assessment scenario no other halons than Halon1301 and Halon-1211 are considered here. Halon-2402 $\left(\mathrm{CBrF}_{2} \mathrm{CBrF}_{2}\right)$ has increased from less than $0.1 \mathrm{pptv}$ in the late 1970s to more than 0.4 pptv by the end of the 1990 s (World Meteorological Organization, 2007); the contribution from Halon-1202 $\left(\mathrm{CBr}_{2} \mathrm{~F}_{2}\right)$ on the other hand is probably very small. I.e., the specified scenario probably underestimates the peak contribution of bromine from anthropogenic emissions by about 1 pptv (about 10-15\%).

As mentioned above, there is now a lot of evidence that short-lived bromine source gases, mainly from natural sources, are contributing to the stratospheric bromine loading. Measurements of bromine monoxide $(\mathrm{BrO})$ in the stratosphere suggest that the current total stratospheric bromine loading is somewhere between 18 and 25 pptv (Pfeilsticker et al., 2000; Sinnhuber et al., 2002; Salawitch et al., 2005; Sinnhuber et al., 2005), indicating that there must be a contribution from short-lived gases to the stratospheric bromine loading (either by direct source gas injection or by product gas injection) of the order of 3 to 8 pptv with a central value of about 5 pptv (World Meteorological Organization, 2007). The exact contribution of the very short-lived gases to the total bromine loading in the real atmosphere is still 

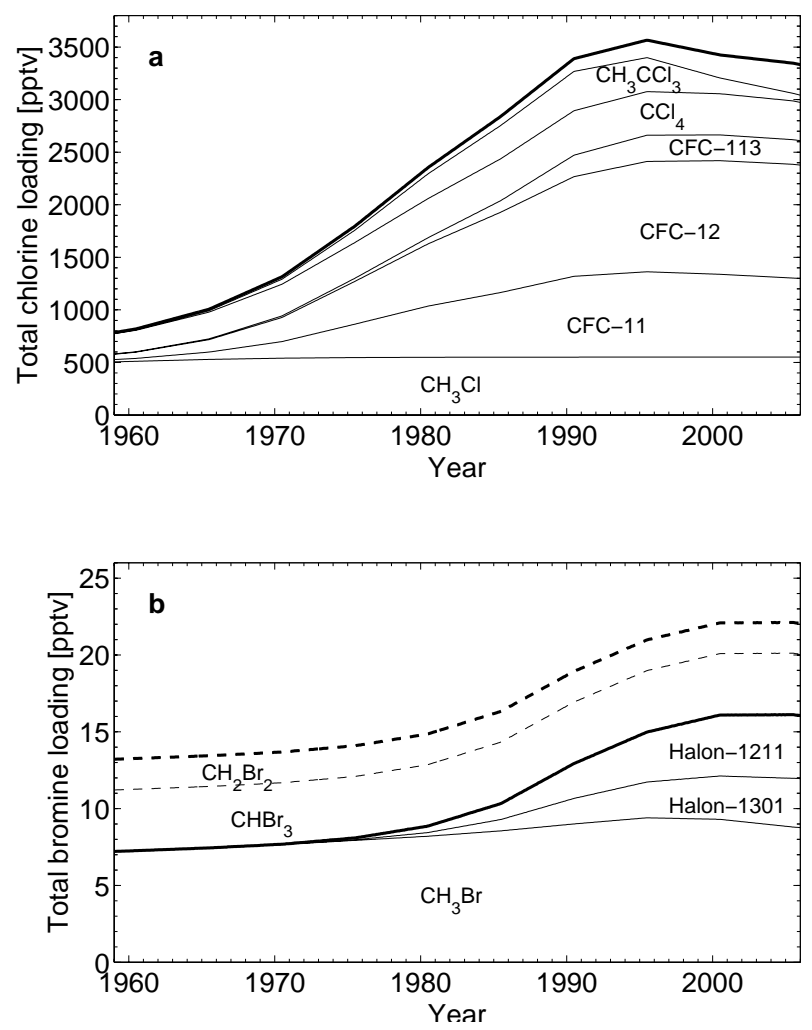

Fig. 1. Source gas scenario (global mean surface mixing ratios) used in the model calculations. (a) Chlorine compounds. The difference between the contribution from the indicated source gases and the total chlorine loading (heavy line) is due to HCFCs (HCFC22, HCFC141b, HCFC142b) and other minor CFCs (CFC114 and CFC115). (b) Total bromine loading due to $\mathrm{CH}_{3} \mathrm{Br}$, Halon-1301, and Halon-1211 only (thick solid line), as well as the assumed additional contribution due to the very short-lived source gases $\mathrm{CHBr}_{3}$ and $\mathrm{CH}_{2} \mathrm{Br}_{2}$ (thick dashed line). The exact contribution of the very short-lived gases to the total bromine loading in the real atmosphere is still unclear at present. Note that the model calculations here did not include any other halons such as Halon-2402.

unclear at present. Although the individual values for the inferred bromine loading differ considerably between the individual studies, a contribution of 5 to 6 pptv from short-lived source gases appears to be the most likely value taking into account the quoted uncertainties from the individual studies (World Meteorological Organization, 2007). Following the recommendations for a sensitivity calculation of the impact of short-lived bromine compounds on ozone trends as part of the 2006 WMO/UNEP Ozone Assessment (R. Salawitch et al., personal communication, 2005), we have also considered a scenario with additional bromine from the two shortlived compounds methylene bromide $\left(\mathrm{CH}_{2} \mathrm{Br}_{2}\right)$ and bromoform $\left(\mathrm{CHBr}_{3}\right)$. The surface mixing ratio of $\mathrm{CH}_{2} \mathrm{Br}_{2}$ was set to $1 \mathrm{pptv}$, in reasonable agreement with the measurements of $\mathrm{CH}_{2} \mathrm{Br}_{2}$ in the stratosphere by Wamsley et al. (1998). The surface mixing ratio of bromoform was specified at $1.33 \mathrm{pptv}$.
This value is at the high end of previous estimates. The modelling studies of Dvortsov et al. (1999) and Nielsen and Douglass (2001) both suggested that bromoform may contribute about $1 \mathrm{pptv}$ to the stratosphere. Sinnhuber and Folkins (2006) estimated that bromoform may contribute between about 0.5 and 3 pptv to stratospheric bromine, depending on the rate and mechanism of removal of bromoform's degradation products in the troposphere and tropopause layer. Since very little is known about possible trends in the contribution of the short-lived bromine compounds to the stratospheric bromine loading we have assumed a constant contribution here. In contrast to the recommended scenario, we have not switched off tropospheric washout of inorganic bromine in these model runs. This means that not all of the bromine released from the two VSLS reaches the stratosphere. The increase in stratospheric $\mathrm{Br}_{\mathrm{y}}$ due to the applied VSLS scenario is about $4 \mathrm{pptv}$, with smaller increases in the lowermost stratosphere where the VSLS (in particular $\mathrm{CH}_{2} \mathrm{Br}_{2}$ ) are not fully degraded in the model.

Three transient model calculations were performed that differed in the specified bromine source gas scenario: (a) A base run that includes the contribution due to $\mathrm{CH}_{3} \mathrm{Br}$, Halon1301, and Halon-1211, (b) one model run that includes additional bromine due to $\mathrm{CH}_{2} \mathrm{Br}_{2}$ and $\mathrm{CHBr}_{3}$, increasing the stratospheric bromine loading by about $4 \mathrm{pptv}$, and (c) one model run that includes the additional $4 \mathrm{pptv}$ of bromine from short-lived compounds but keeps the bromine loading fixed at 1959 levels, i.e., without anthropogenic bromine emissions. These transient model runs were initialized in 1959 and integrated until the year 2100 . However, here we will only focus on the period between 1980 and 2005. This is the period were most of the increase in bromine due to anthropogenic emissions occurred and it coincides with the period over which satellite measurements of global ozone are available.

In addition we performed a set of sensitivity calculations to estimate the ozone loss effectiveness of bromine relative to chlorine, following as closely as possible the methodology described by Daniel et al. (1999). For these sensitivity calculations the model was integrated over 11 years starting from 1998 conditions with fixed source gas concentrations. Only the last year of these 11-year integrations was then used for the analyses.

\section{Results and discussion}

\subsection{The contribution of bromine to ozone trends}

Fig. 2 shows the evolution of total ozone at Northern Hemisphere mid-latitudes $\left(30^{\circ} \mathrm{N}-60^{\circ} \mathrm{N}\right)$ for three model runs: the base run, the run with enhanced bromine from shortlived compounds and the model run with fixed 1959 bromine loading (i.e., "no anthropogenic bromine"). Shown are the changes of the annual mean ozone columns relative to the 


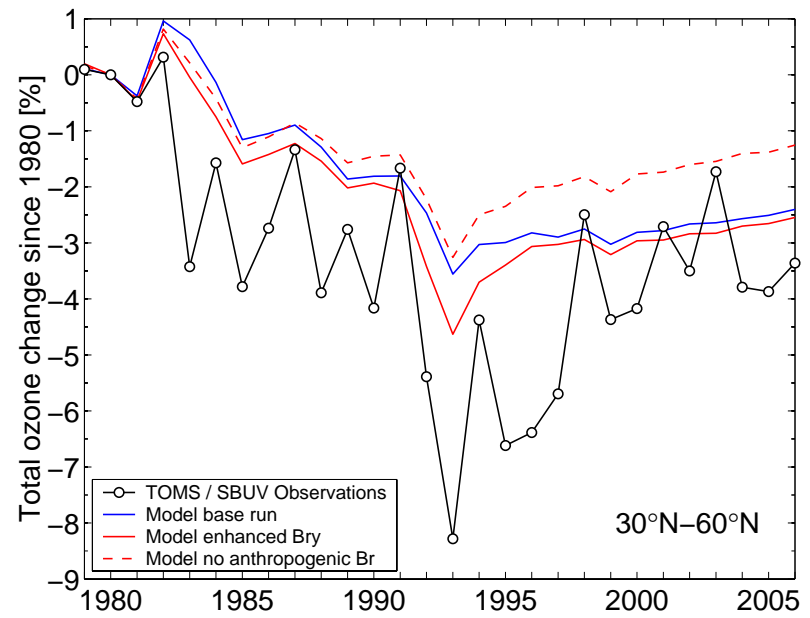

Fig. 2. Change in Northern Hemisphere mid-latitude $\left(30^{\circ} \mathrm{N}-\right.$ $60^{\circ} \mathrm{N}$ ) column ozone since 1980 .

1980 annual mean. For comparison also the evolution from observations of the merged Total Ozone Mapping Spectrometer (TOMS)/Solar Backscatter Ultraviolet (SBUV) data set is shown. The merged TOMS/SBUV total ozone data set is from Version 8, Revision 03, available from the NASA Goddard Space Flight Center (http://hyperion.gsfc.nasa.gov/ Data_services/merged).

At Northern Hemisphere mid-latitudes the model shows a decrease of total ozone of about 3\% between 1980 and 2005 , with the evolution of total ozone agreeing generally well with the TOMS observations. The model run with enhanced bromine due to short-lived compounds leads to an increased downward ozone trend, in agreement with the model calculations of Salawitch et al. (2005). The model shows a slow increase in total ozone since the late 1990s as a result of the slight reductions in the specified chlorine and bromine loading. The question if and when ozone will recover to its pre-1980 levels will also critically depend on the increase of greenhouse gases during the next decades (Chipperfield and Feng, 2003).

Both model and observations show the largest ozone reductions in the years 1992 and 1993, as a result of the increased aerosol surface area following the eruption of the Mt. Pinatubo volcano in June 1991. For this period with enhanced aerosol surface area there is also the largest difference found between the model runs with and without additional bromine from short-lived compounds. Although the model calculation with enhanced bromine loading agrees in general better with the observations, the model still underestimates the magnitude of the observed ozone reduction in 1993. Part of the ozone reductions in 1993 may have resulted from changes in dynamics and transport (e.g., Hadjinicoaou et al., 1997) not captured by our model. Similarly, the increase of observed total ozone after the mid-1990s may be partly the result of changes in dynamics and transport as a result of increases in the planetary wave activity (Dhomse et al., 2006). An interesting question here is whether the eruption of Mt. Pinatubo may have injected additional bromine into the stratosphere. $\mathrm{BrO}$ has been observed in volcanic plumes (Bobrowski et al., 2003) and it has been suggested that the eruption of Mt. Pinatubo in 1991 could have been an important source of bromine to the stratosphere (Bureau et al., 2000). However, there are currently no indications for a significant increase in the stratospheric bromine loading following the Mt. Pinatubo eruption in 1991, so this issue remains speculative at present.

The model run with fixed 1959 bromine loading ("no anthropogenic bromine") shows a much smaller downward ozone trend and a more rapid increase of ozone over the past years. For 2005 the modelled ozone loss without anthropogenic bromine is only about $55 \%$ of the total modelled loss at Northern Hemisphere mid-latitudes. In this sense, anthropogenic bromine emissions are responsible for $\approx 45 \%$ of the modelled column ozone loss at Northern Hemisphere midlatitudes. (Note that since a large fraction of the bromine induced ozone loss is due to the combined $\mathrm{BrO} / \mathrm{ClO}$ catalytic cycle (e.g. Daniel et al., 1999), the effect of bromine would have been smaller in the absence of anthropogenic chlorine emissions.) Although the increase in the total bromine loading was only about $1 / 140$ that of the increase in the total chlorine loading over the period 1980 to 2005 (about 7 pptv compared to about 1000 pptv, respectively), including the bromine increase nearly doubled the modelled downward ozone trend. This means that on a per molecule basis bromine is about a hundred times more effective in destroying ozone at Northern Hemisphere mid-latitudes. This effectiveness results partly from the quicker release of bromine from its source gases as compared to chlorine and partly from the greater chemical effectiveness (as expressed by the socalled $\alpha$ factor). We discuss this in more detail in Section 3.2 below.

Figs. 3-5 shows similar results as Fig. 2, but for Southern Hemisphere mid-latitudes $\left(30^{\circ} \mathrm{S}-60^{\circ} \mathrm{S}\right)$, the tropics $\left(30^{\circ} \mathrm{N}-\right.$ $30^{\circ} \mathrm{S}$ ) and the region from $60^{\circ} \mathrm{S}-60^{\circ} \mathrm{N}$, respectively.

Both modelled and observed ozone reductions are larger over the Southern Hemisphere mid-latitudes compared to the Northern Hemisphere. While for the Northern Hemisphere the model underestimates the ozone reduction following the eruption of Mt. Pinatubo, this is not the case for the Southern Hemisphere. The reason for the different behavior of the Pinatubo ozone anomalies for the two hemispheres is still unclear at present. However, in general the model reproduces well the observed ozone trend. For the Southern Hemisphere mid-latitudes the model run with no anthropogenic bromine produces an ozone depletion of $65 \%$ of the total modelled loss between 1980 and 2005. I.e., the relative contribution of anthropogenic bromine emissions to the trend in total ozone is a bit smaller for the Southern Hemisphere than it is for the Northern Hemisphere. 


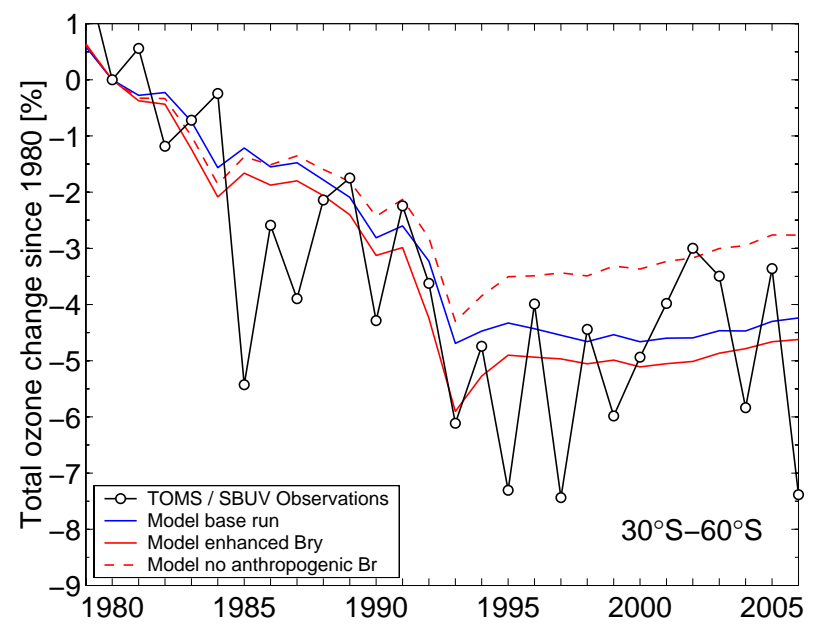

Fig. 3. As for Fig. 2 but for Southern Hemisphere mid-latitudes $\left(30^{\circ} \mathrm{S}-60^{\circ} \mathrm{S}\right)$.

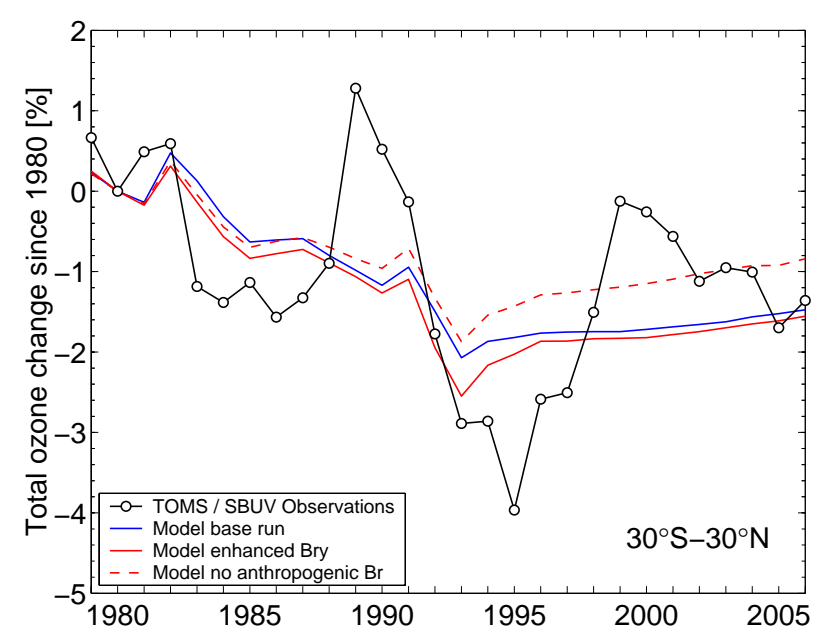

Fig. 4. As for Fig. 2 but for the tropics $\left(30^{\circ} \mathrm{S}-30^{\circ} \mathrm{N}\right)$. Note the change in scale compared to Figs. 2, 3, and 5

Even in the tropics there is reasonable agreement between the modelled and observed total ozone evolution (Fig. 4). Interestingly, there appears to be a relatively large solar signal present in the tropical total ozone observations, with reduced levels of ozone during the minimum periods of solar activity in the middle of the 1980s and the 1990s and with enhanced ozone during solar maximum periods (World Meteorological Organization, 2007, Fig. 3-4). Remember that there is no solar cycle effect included in the model calculations presented here. Figure 5 summarizes the results for the overall region between $60^{\circ} \mathrm{S}$ and $60^{\circ} \mathrm{N}$.

Figure 6 shows the profile of the modelled ozone change between 1980 and 2005 for Northern Hemisphere midlatitudes $\left(47^{\circ} \mathrm{N}\right)$. A comparison of the modelled ozone trend with results from other 2-D and 3-D models as well as observations is shown in Fig. 3-24 of the 2006 WMO Ozone

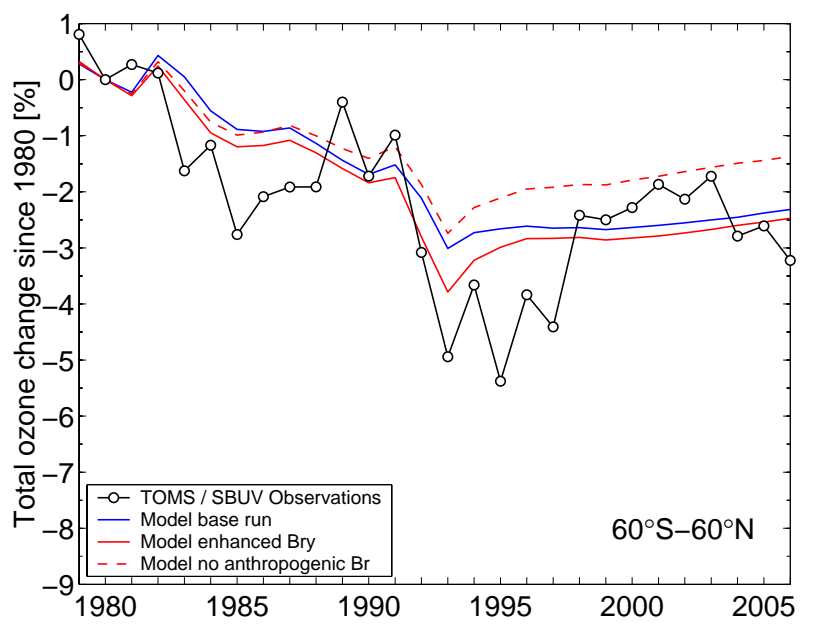

Fig. 5. As for Fig. 2 but for global ozone between $60^{\circ} \mathrm{S}$ and $60^{\circ} \mathrm{N}$.

Assessment (World Meteorological Organization, 2007). There is a relatively large modelled ozone decrease in the tropopause region, as a result of the model calculating some chlorine activation in this region (corresponding to $\mathrm{ClO}$ noon values of about $50 \mathrm{pptv}$ ). Again, it is not clear how realistic the results are for the upper troposphere and the tropopause region, given the model's limitations in these regions.

It is evident from Fig. 6 that anthropogenic bromine emissions have a very large effect on the ozone trend in the stratosphere between the tropopause and about $25 \mathrm{~km}$ altitude. Above $30 \mathrm{~km}$ altitude the effect of bromine is small. Except for the lowermost stratosphere, the inclusion of enhanced bromine due to short-lived source gases has only a minor effect on the calculated ozone decrease. The picture changes, however, for periods of enhanced aerosol surface area. Figure 7 shows the calculated ozone change for March between 1980 and 1993. Under these conditions the enhanced bromine loading leads to a significant increase in modelled downward ozone trends over much of the lower stratosphere, in qualitative agreement with the calculations by Salawitch et al. (2005).

\subsection{Bromine $\alpha$}

As noted above, the greater effectiveness of bromine compared to chlorine for ozone destruction is the result of two effects: (a) most of the bromine source gases have a shorter stratospheric lifetime than the chlorine source gases, so that the ratio of inorganic bromine $\left(\mathrm{Br}_{\mathrm{y}}\right)$ to inorganic chlorine $\left(\mathrm{Cl}_{\mathrm{y}}\right)$ in the lower stratosphere is larger than the ratio of total bromine to total chlorine, and (b) bromine is chemically more effective than chlorine in destroying ozone. The chemical effectiveness of bromine relative to chlorine for ozone destruction is given by the so-called $\alpha$-factor. Locally in the stratosphere the $\alpha$-factor is defined as the change in ozone due to a change in bromine per inorganic bromine 


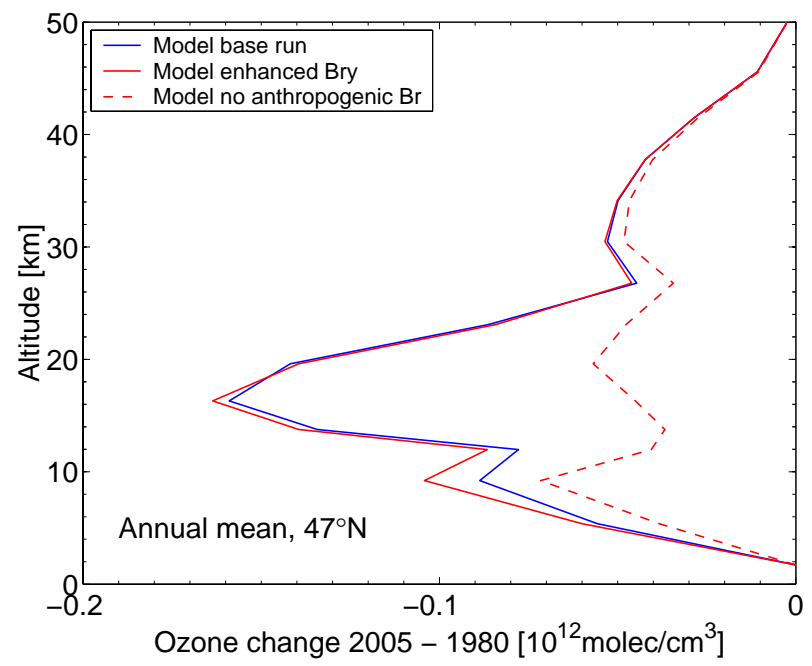

Fig. 6. Modelled annual mean ozone change at $47^{\circ} \mathrm{N}$ between 1980 and 2005 in molecules $/ \mathrm{cm}^{3}$.

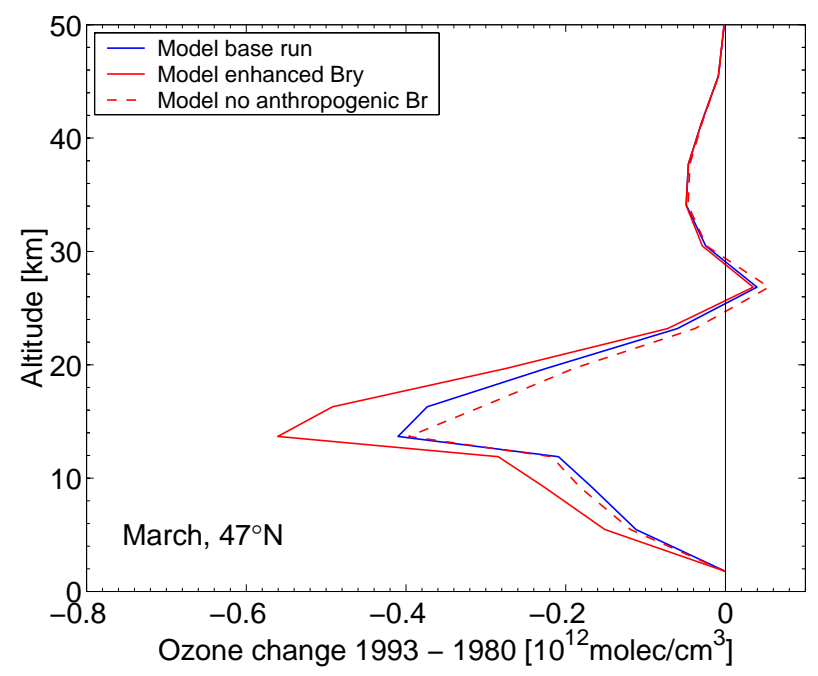

Fig. 7. Same as for Fig. 6 but for modelled ozone differences between March 1980 and March 1993. This illustrates that the effect of additional bromine from very short-lived source gases is largest during periods of enhanced stratospheric aerosol loading.

molecule, divided by the change in ozone due to chlorine per inorganic chlorine molecule (Daniel et al., 1999):

$$
\alpha=\frac{\Delta \mathrm{O}_{3-\mathrm{Bry}_{\mathrm{y}}} / \Delta \mathrm{Br}_{\mathrm{y}}}{\Delta \mathrm{O}_{3-\mathrm{Cl}_{\mathrm{y}}} / \Delta \mathrm{Cl}_{\mathrm{y}}} .
$$

An effective value of $\alpha_{\text {column }}$ for column ozone loss can be defined by the change in column ozone due to bromine per inorganic bromine molecule, divided by the change in column ozone due to chlorine per inorganic chlorine molecule: $\alpha_{\text {column }}=\frac{\Delta \mathrm{O}_{3-\text { column }-\mathrm{Bry}_{\mathrm{y}} / \Delta \mathrm{Br}_{\mathrm{y}}}}{\Delta \mathrm{O}_{3} \text {-column }-\mathrm{Cl}_{\mathrm{y}} / \Delta \mathrm{Cl}_{\mathrm{y}}}$, assuming that the ratio $\Delta \mathrm{Cl}_{\mathrm{y}} / \Delta \mathrm{Br}_{\mathrm{y}}$ is constant with altitude. Similarly one can define also an effective value of $\alpha_{\text {global }}$ for global ozone loss.

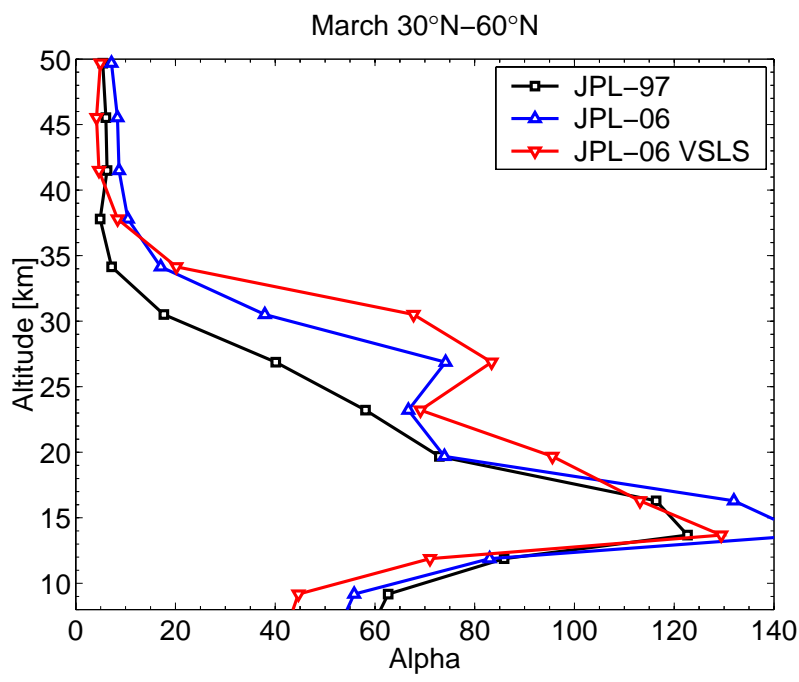

Fig. 8. Calculated bromine $\alpha$ as a function of altitude during March at Northern Hemisphere mid-latitudes $\left(30-60^{\circ} \mathrm{N}\right)$. The solid line is from the standard model run while the dashed line is from the model run with enhanced bromine loading due to very short-lived source gases. For comparison also the calculations for JPL-97 reaction rate recommendations and without additional bromine are shown (black solid line with symbols).

Following Daniel et al. (1999) we have calculated $\alpha$ here by performing three model runs: (a) a standard run, (b) a model run with increased chlorine loading by increasing CFC-11 as the reference gas, and (c) a model run with increased bromine loading by including an artifical source gas with the same life time as CFC-11 but which releases bromine instead of chlorine. This procedure ensures that the ratio of $\Delta \mathrm{Cl}_{\mathrm{y}} / \Delta \mathrm{Br}_{\mathrm{y}}$ is constant throughout the model stratosphere. Technically, we have increased chlorine and bromine by 10,30 , and $50 \%$ over the base run. The results presented below are taken from the calculations with a 30\% increase in chlorine and bromine. Very similar results are obtained from the calculations with 10 and 50\% increase (changes in annual mean global alpha by less than 10\%). However, the $10 \%$ increase resulted in certain regions in ozone changes that were too small for a reliable calculation of local alpha values.

We have calculated $\alpha$ for two scenarios: The standard scenario without bromine from short-lived compounds and the other scenario with $\mathrm{CH}_{2} \mathrm{Br}_{2}$ and $\mathrm{CHBr}_{3}$ included. For both scenarios $\alpha$ is calculated in the same way by increasing bromine from the CFC-11-like tracer. Moreover, we have also performed yet another set of model runs to calculate $\alpha$ using JPL-97 reaction rate recommendations (and without bromine from short-lived compounds) to allow a quantitative comparison with the results of Daniel et al. (1999).

Figure 8 shows the profile of the local $\alpha$-factor for Northern Hemisphere mid-latitudes during March with and without additional bromine from VSLS. For comparison with Daniel et al. (1999) also the calculations using JPL-97 


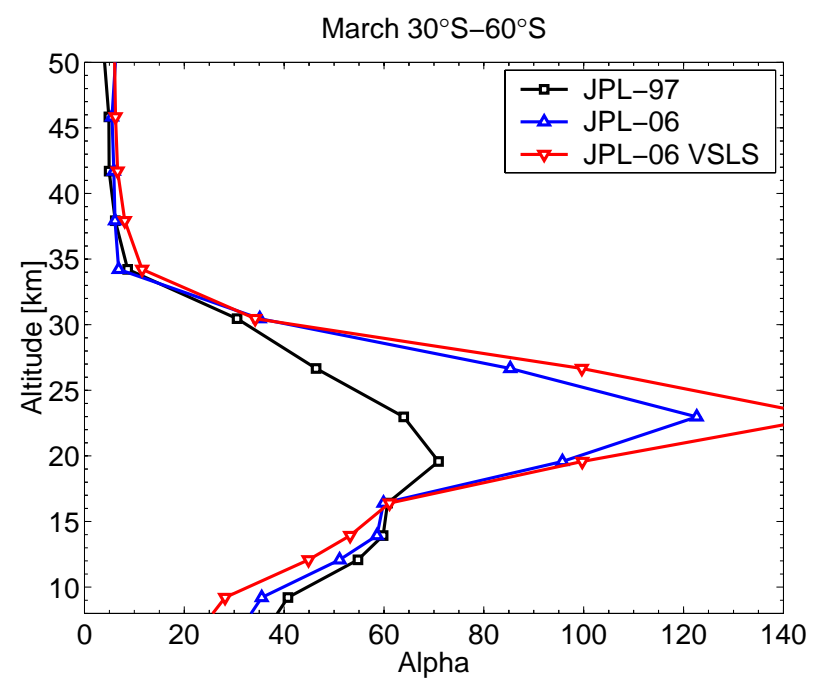

Fig. 9. Same as Fig. 8 but for $30-60^{\circ} \mathrm{S}$.

reaction rates are shown. Our profile of $\alpha$ for JPL-97 kinetics looks qualitatively similar to the results shown by Daniel et al. (1999), but also shows some differences: The peak value of $\alpha$ of about 120 at $15 \mathrm{~km}$ is larger than the value shown by Daniel et al. (1999). Secondly, while the calculations of $\alpha$ by Daniel et al. (1999) continuously increased towards the tropopause and into the upper troposphere, our $\alpha$ shows lower values again in the tropopause region.

Figure 8 shows that the change in reaction rate kinetics between JPL-97 and JPL-06 has led to a significant increase in $\alpha$ above about $15 \mathrm{~km}$ altitude and to a slight decrease in the lowermost stratosphere. Additional bromine due to VSLS lead to an increase of $\alpha$ in the mid-stratosphere above about $20 \mathrm{~km}$ altitude and to a reduction below. Essentially the same behavior can be seen also in the Southern Hemisphere during March (Fig. 9). During autumn the maximum in $\alpha$ is found in the mid-stratosphere at about $25 \mathrm{~km}$ altitude.

Effective $\alpha_{\text {column }}$ values as a function of month and latitude are shown in Fig. 10. These calculations were done with the most recent reaction rate recommendations and in the presence of enhanced bromine from short-lived compounds. As can be seen, there is a minimum in column $\alpha$ in the tropics with values around 50, and higher values of around 60 to 70 in the mid-latitudes of both hemispheres. Very large values of $\alpha$ are reached in the high latitudes during summer and autumn, in particular in the Northern Hemisphere, with values as high as 130. These high values of column $\alpha$ in the summer/autumn high latitudes are in accordance with very high local values $(\alpha \geq 300)$ at around $25 \mathrm{~km}$ altitude. They correspond to situations where ozone loss is mainly controlled by nitrogen oxides $\left(\mathrm{NO}_{\mathrm{x}}\right)$ and result from the fact that an increase of chlorine will lead to a decrease in $\mathrm{NO}_{\mathrm{x}}$, compensating the effect of the chlorine increase for ozone loss, while an increase in bromine has no significant effect on $\mathrm{NO}_{\mathrm{x}}$.

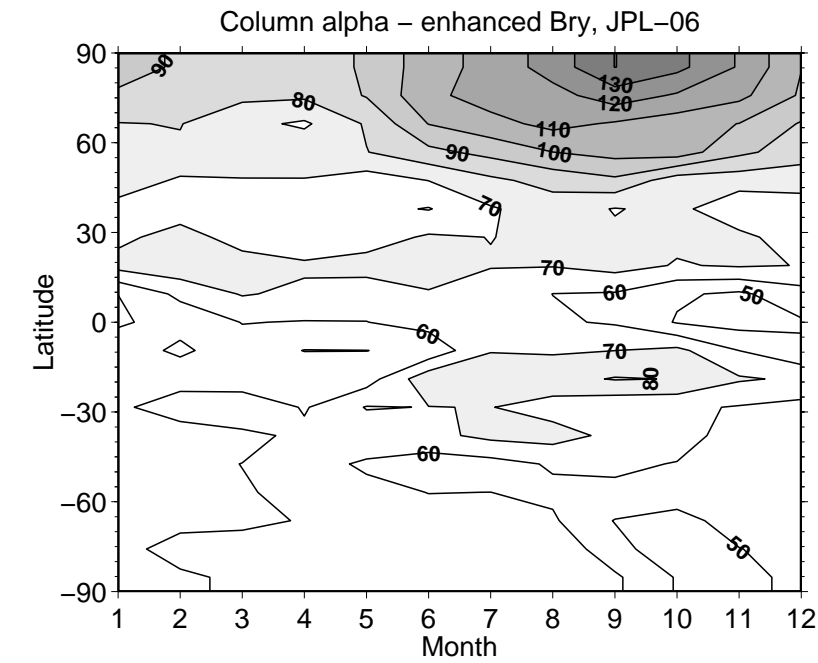

Fig. 10. Calculated $\alpha_{\text {column }}$ from the model run with enhanced bromine loading due to very short-lived source gases as function of latitude and season. Values larger than 70 are shaded.

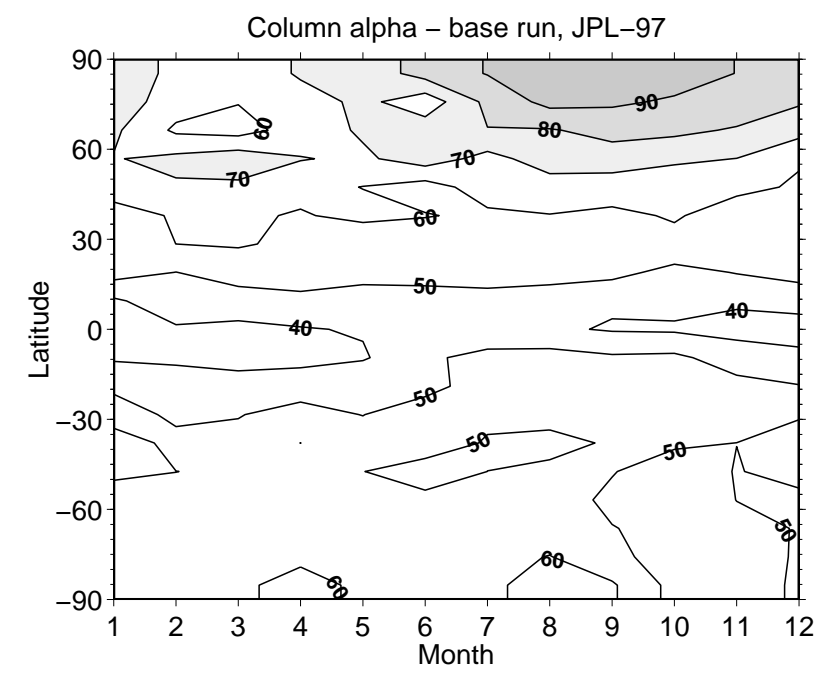

Fig. 11. As Fig. 10 but for JPL-97 kinetics and without additional Bry from short-lived compounds.

The global annual mean value of $\alpha$ from these model runs is $\alpha_{\text {global }}=64$, a value that is considerably larger than the value of $\alpha_{\text {global }}=45$ given by Daniel et al. (1999). For the scenario without the short-lived bromine source gases the global $\alpha$ increases to $\alpha_{\text {global }}=66$. Changes in reaction rates since JPL-97 have contributed to an increase in the calculated value of $\alpha$. For the scenario using JPL-97 reaction rate recommendations and without additional bromine from short-lived compounds we get a global value of $\alpha_{\text {global }}=55$ (Fig. 11). At least part of the increase in $\alpha$ between JPL-97 and JPL-05 is due to a decrease in the effectiveness of chlorine induced ozone loss, as a result of a decrease in modelled $\mathrm{ClO}$ due to the increase in $\mathrm{NO}_{\mathrm{x}}$ and a decrease in the rate constant for the reaction of $\mathrm{ClO}$ with $\mathrm{HO}_{2}$. 
Recently, updated values of $\alpha$ were calculated in support of the $2006 \mathrm{WMO} / \mathrm{UNEP}$ Ozone Assessment also with the University of Illinois at Urbana-Champaign (UIUC) 2-D model and with the AER 2-D model. Both models calculate a global mean $\alpha$ of 61 using a preliminary version of JPL06 kinetics in the presence of 6 pptv of additional bromine from short-lived compounds (D. Wuebbles and D. Weisenstein, personal communication, 2006). Taking into account the calculations from the UIUC and AER models as well as our calculations, the 2006 WMO/UNEP Ozone Assessment has now adopted a value of 60 for $\alpha$ (World Meteorological Organization, 2007).

\section{Summary and conclusions}

We have calculated the changes in stratospheric ozone over the period 1980 to 2005 for specified changes in the halogen loading, using a 2-D model. The modelled ozone trend agrees reasonably well with the observed trend in column ozone derived from the merged TOMS/SBUV data set, over both the Northern and Southern Hemisphere. A large fraction of the modelled downward ozone trend at mid-latitudes is due to anthropogenic bromine emissions. E.g., the model run with the fixed 1959 bromine loading, corresponding to a situation without anthropogenic bromine emissions, produces a downward trend in Northern Hemisphere mid-latitude total ozone that is only $\approx 55 \%$ of the modelled ozone trend including all halogen increases. In this sense anthropogenic bromine emissions are responsible for $\approx 45 \%$ of the modelled Northern Hemisphere mid-latitude ozone reduction between 1980 and 2005. Because the contribution of Halon-2402 was not considered in the present source gas scenario, the increase in bromine loading due to anthropogenic emissions is probably underestimated here by about $10-15 \%$. This means that the contribution of anthropogenic bromine emissions to the ozone trend could be even larger, with bromine responsible for about half of the halogen-induced downward ozone trend at Northern Hemisphere mid-latitudes.

The impact of bromine on ozone depletion is largest in the lower stratosphere. The addition of bromine from shortlived source gases increases the modelled downward ozone trend and is particularly important for periods of enhanced stratospheric aerosol loading following volcanic eruptions. The chemical effectiveness of bromine relative to chlorine for stratospheric ozone destruction, expressed by the $\alpha$ factor, decreases slightly on a global average if the enhanced stratospheric bromine loading due to short-lived source gases is taken into account. Global annual mean $\alpha$ from our model calculations decrease from 66 for the scenario without short-lived bromine source gases to 64 including short-lived bromine source gases. These values of $\alpha$ are considerably higher than the previously used value of 45 (Daniel et al., 1999). Updates of reaction rate recommendations have contributed to the increase in $\alpha$ but can not explain all the dif- ferences between our calculations and previously published results. Because $\alpha$ is directly used in the calculation of ozone depletion potentials for bromine source gases a better understanding of the reasons for the differences in $\alpha$ between different models is important. One of the next steps needed is a study that compares calculations of $\alpha$ for a collection of independent models to assess the possible range of $\alpha$.

Acknowledgements. Parts of this work were supported by the EU project SCOUT-O3 and by the Helmholtz Virtual Institute Pole-Equator-Pole. We thank Malcolm Ko, Debra Weisenstein and Don Wuebbles for sharing their $\alpha$ results prior to publication and for helpful comments.

Edited by: M. Dameris

\section{References}

Bobrowski, N., Hönninger, G., Galle, B., and Platt, U.: Detection of bromine monoxide in a volcanic plume, Nature, 423, 273-276, 2003.

Bureau, H., Keppler, H., and Métrich, N.: Volcanic degassing of bromine and iodine: Experimental fluid/melt partitioning data and applications to stratospheric chemistry, Earth Planet. Sci. Lett., 183, 51-60, 2000.

Chipperfield, M. P.: Multiannual simulations with a threedimensional chemical transport model, J. Geophys. Res., 104, 1781-1805, 1999.

Chipperfield, M. P. and Feng, W.: Comment on: Stratospheric Ozone Depletion at northern mid-latitudes in the 21 st century: The importance of future concentrations of greenhouse gases nitrous oxide and methane, Geophys. Res. Lett., 30, 1389, doi:10.1029/2002GL016353, 2003.

Daniel, J. S., Solomon, S., Portmann, R. W., and Garcia, R. R.: stratospheric ozone destruction: The importance of bromine relative to chlorine, J. Geophys. Res., 104, 23871-23880, 1999.

Dhomse, S., Weber, M., Wohltmann, I., Rex, M., and Burrows, J. P.: On the possible causes of recent increases in northern hemispheric total ozone from a statistical analysis of satellite data from 1979 to 2003, Atmos. Chem. Phys., 6, 1165-1180, 2006, http://www.atmos-chem-phys.net/6/1165/2006/.

Dvortsov, V. L., Geller, M. A., Solomon, S., Schauffler, S. M., Atlas, E. L., and Blake, D. R.: Rethinking reactive halogen budgets in the mid-latitude lower stratosphere, Geophys. Res. Lett., 26, 1699-1702, 1999.

Feng, W., Chipperfield, M. P., Dorf, M., and Pfeilsticker, K.: Midlatitude ozone changes: Studies with a 3-D CTM forced by ERA40 analyses, Atmos. Chem. Phys. Discuss., 7, 2357-2369, 2007, http://www.atmos-chem-phys-discuss.net/7/2357/2007/.

Hadjinicolaou, P., Pyle, J. A., Chipperfield, M. P., and Kettleborough, J. A.: Effect of interannual meteorological variability on mid-latitude ozone, Geophys. Res. Lett., 24, 2993-2996, 1997.

Kinnersley, J. S.: The climatology of the stratospheric THIN AIR model, Q. J. Roy. Meteorol. Soc., 122, 219-252, 1996.

Kinnersley, J. S. and Tung, K.-K.: Modeling the global interannual variability of ozone due to the equatorial QBO and to extratropical planetary wave variability, J. Atmos. Sci., 55, 1417-1428, 1998. 
Kinnersley, J. S.: Interannual variability of stratospheric zonal wind forced by the northern lower-stratospheric large-scale waves, J. Atmos. Sci., 55, 2270-2283, 1998.

Montzka, S. A., Butler, J. H., Hall, B. D., Mondeel, D. J., and Elkins, J. W.: A decline in tropospheric organic bromine, Geophys. Res. Lett., 30, 1826, doi:10.1029/2003GL017745, 2003.

Nielsen, J. E. and Douglass, A. R.: A simulation of bromoform's contribution to stratospheric bromine, J. Geophys. Res., 106, 8089-8100, 2001.

Pfeilsticker, K., Sturges, W. T., Bösch, H., Camy-Peyret, C., Chipperfield, M. P., Engel, A., Fitzenberger, R., Müller, M., Payan, S., and Sinnhuber, B.-M.: Lower stratospheric organic and inorganic bromine budget for the arctic winter 1998/99, Geophys. Res. Lett., 27, 3305-3308, 2000.

Salawitch, R. J., Weisenstein, D. K., Kovalenko, L. J., Sioris, C. E., Wennberg, P. O., Chance, K., Ko, M. K. W., and McLinden, C. A.: Sensitivity of ozone to bromine in the lower stratosphere, Geophys. Res. Lett., 32, L05811, doi:10.1029/2004GL021504, 2005.

Sander, S. P., Finlayson-Pitts, B. J., Friedl, R. R., et al.: Chemical Kinetics and Photochemical Data for Use in Atmospheric Studies, Evaluation No. 15, NASA JPL Publication 06-2, 2006.

Schofield, R., Kreher, K., Connor, B. J., Johnston, P. V., Thomas, A., Shooter, D., Chipperfield, M. P., Rodgers, C. D., and Mount, G. H.: Retrieved tropospheric and stratospheric BrO columns over Lauder, New Zealand, J. Geophys. Res., 109, D14304, doi:10.1029/2003JD004463, 2004.
Sinnhuber, B.-M., Arlander, D. W., Bovensmann, H., et al.: Comparison of measurements and model calculations of stratospheric bromine monoxide, J. Geophys. Res., 107, 4398, doi:10.1029/2001JD000940, 2002.

Sinnhuber, B.-M., Rozanov, A., Sheode, N., et al.: Global observations of stratospheric bromine monoxide from SCIAMACHY, Geophys. Res. Lett., 32, L20810, doi:10.1029/2005GL023839, 2005.

Sinnhuber, B.-M. and Folkins, I.: Estimating the contribution of bromoform to stratospheric bromine and its relation to dehydration in the tropical tropopause layer, Atmos. Chem. Phys., 6, 4755-4761, 2006, http://www.atmos-chem-phys.net/6/4755/2006/.

Sioris, C. E., Kovalenko, L. J., McLinden, C. A., et al.: Latitudinal and vertical distribution of bromine monoxide in the lower stratosphere from Scanning Imaging Absorption Spectrometer for Atmospheric Chartography limb scattering measurements, J. Geophys. Res., 111, D14301, doi:10.1029/2005JD006479, 2006.

Wamsley, P. R., Elkins, J. W., Fahey, D. W., et al.: Distribution of halon-1211 in the upper troposphere and lower stratosphere and the 1994 total bromine budget, J. Geophys. Res., 103, 1513$1526,1998$.

World Meteorological Organization: Scientific Assessment of Ozone Depletion: 2006, Global Ozone Research and Monitoring Project - Report No. 50, Geneva, Switzerland, 2007. 